\begin{tabular}{ccc}
\hline International Journal of Medicine, $9(1)(2021) 40-47$ & International Journal of Medicine \\
SPC & Website: $w w w . s c i e n c e p u b c o . c o m / i n d e x . p h p / I J M$ \\
Research paper
\end{tabular}

\title{
Loneliness and Cardiovascular Disease
}

\author{
Shashi K. Agarwal MD. * \\ Center for Contemporary and Complementary Cardiology 2227 US Highway 1, \\ Suite 309, North Brunswick, NJ 08902, USA \\ *Corresponding author E-mail: usacardiologist@gmail.com
}

\begin{abstract}
Loneliness is a silent social epidemic that affects more than one third of the US population. Cardiovascular diseases impart a huge morbidity, mortality, and financial burden on our society. The detrimental role of loneliness in cardiovascular diseases is being increasingly recognized. Besides having a direct molecular effect on cardiovascular diseases, loneliness also encourages poor compliance with healthy lifestyles, that play a significant role in preventing and improving cardiovascular diseases. This brief review highlights the ominous effects of loneliness on cardiovascular diseases.
\end{abstract}

Keywords: Atherosclerosis; Cardiovascular Diseases; Coronary Artery Disease; Loneliness; Social Isolation.

\section{Introduction}

Loneliness and social isolation are closely related, with loneliness being the subjective manifestation of social isolation (Cacioppo \& Hawkley 2005, Heinrich \& Gullone 2006). Loneliness is a worldwide phenomenon (Rico-Uribe et al. 2016), and its prevalence is on the rise(Madsen et al. 2019). It affects all population groups, from kindergarten students to senior citizens (Asher 1984, Cassidy \& Asher 1992, De Jong Gierveld \& van Tilburg 1999, Victor et al. 2005). A recent study in the United States of America (US) by Cigna, of adults aged 18 and older found that 46 percent reported "sometimes or always feeling alone" (Cigna 2018).

Loneliness imparts significant harm to our physical and mental systems (Richard et al. 2017). It is detrimentally associated with several disorders, including obesity (Lauder et al. 2006), cancer (Drageset et al. 2013), and cognitive decline (Wilson et al. 2007). It is associated with premature mortality (Rico-Uribe et al. 2014). Psychiatric dysfunctions affected include depression (Cacioppo et al. 2010), alcoholism (Akerlind \& Hörnquist 1992), suicidal ideation (Akerlind et al. 2007), aggressive behaviors, and impulsivity (Cacioppo et al. 2014). Loneliness is also increasingly being pathologically implicated in all phases of cardiovascular diseases (CVD) (Valtorta et al. 2018).

\section{Discussion}

Cardiovascular diseases (CVDs) are common in the US, with the American Heart Association estimating that they affect about half the US population (Benjamin et al. 2019). With more than 650,000 Americans dying from CVDs each year, they are also the leading cause of death in the US (Roth et al. 2018). CVDs include hypertension (HTN), coronary artery disease (CAD) and coronary heart disease (CHD), cerebrovascular disease, heart failure (HF), rheumatic heart disease, congenital heart disease, cardiomyopathies, and peripheral vascular disease (WHO. int). HTN is a major public health problem in the United States. The recent decrease in its threshold to $<130 / 89$ $\mathrm{mm} / \mathrm{Hg}$ has raised its prevalence to $45.4 \%$ of the US population (105 million adults) from $32.0 \%$ ( 74.1 million), based on 2014 guidelines (Bundy et al. 2018). It is associated with $25 \%$ of all CVD deaths and these represent more deaths than those from any other modifiable cause (Cheng et al. 2014, Danaei et al. 2009). CHD is present in 15.5 million Americans (Mozaffarian et al. 2016) and was associated with 366,000 deaths in 2017 (Healthline.com). Atherosclerosis is usually the underlying cause in these HTN related deaths (Hansson 2005). Stroke is also a major cardiovascular disease in the US (Go et al. 2014). Projections show that by 2030, an additional 3.4 million US adults aged $\geq 18$ years (representing $3.88 \%$ of the adult population), will have had a stroke - representing a $20.5 \%$ increase in prevalence from 2012 (Ovbiagele et al. 2013). Stroke is the leading cause of serious long-term adult disability in the US (Roger et al. 2012). Based on data from NHANES 2013 to 2016, an estimated 6.2 million Americans $\geq 20$ years of age suffer from HF (CDC 2019). Projections show that the prevalence of HF will increase $46 \%$ from 2012 to 2030 , resulting in $>8$ million people $\geq 18$ years of age being diagnosed with $\mathrm{HF}$ (Heidenreich et al. 2013). Elevated blood lipid concentrations, or dyslipidemia, currently affect $13 \%$ of the US population and are strong predictors of cardiovascular disease (Carroll et al. 2017). Diabetes Mellitus (DM) is a major disorder in the USA (Boyle et al. 2010). CVD affects $32.2 \%$ of all persons with type $2 \mathrm{DM}$ and is the leading cause of death in this population (Einarson et al. 2018). Chronic kidney disease (CKD) is growing rapidly in the US (CDC 2020). CVD is common in patients with CKD and may affect 33\% of the renal patients (Srivastava et al. 2017). It is the most common cause of death in these patients before the disease reaches an end-stage renal disease status (Schrier 2007). Metabolic syndrome has a prevalence of 33\% in the USA with more women than men having this condition (Aguilar et al. 
2015). This clustering of risk factors is associated with an increased risk for CVD morbidity and mortality (Gami et al. 2007). Mottillo and his group determined that the increased risks faced by these individuals include a 2 -fold increase in major cardiovascular outcomes and a 1.5 -fold increase in all-cause mortality (Mottillo et al. 2010). Obesity affects 42.4 percent of Americans 20 years old or older, and the prevalence has been steadily rising (Craig et al. 2020). Both overweight and obese individuals are at an increased risk for CVD compared with those with normal body weight (Asad et al. 2018). Psychosomatic stress, often a part of loneliness, also has significant negative repercussions on CVD morbidity and mortality (Nabi et al. 2013). Depression is common and affects nearly 16 million people in the US (Liu et al. 2015). It is strongly linked with CVDs such as angina, myocardial infarction, heart failure, and CHD related mortality (Poole et al. 2019). A meta-analysis estimated that depression was associated with a $30 \%$ excess risk for coronary heart disease and its presence resulted in a poorer prognosis (Gan et al. 2014, Blumenthal et al. 2014). Co-morbid CHD and depression result in a 2-fold increase in cardiac and all-cause mortality (Dickens et al. 2006). Sleep disturbances have also been linked to an increased CVD risk (King et al. 2008).

\subsection{Impact of loneliness on CVD and its major risk factors}

In a study of 5397 adults, Valtorta and his group found that loneliness had a $27 \%$ increased risk of cardiovascular disease over a mean follow-up of 5.4 years (Valtorta et al. 2018). Men living alone appear to have a worse prognosis from CVD than women (Gandhi et al. 2019). Chronic loneliness also increases CVD mortality (Holt-Lunstad et al, 2015), independent of other risk factors (Holt-Lunstad et al. 2010), such as HTN, smoking, and obesity (Xia \& Li 2017).

Loneliness is a risk factor for HTN, and this association strengthens with increasing age (Hawkley et al. 2006). Lonely people also face higher blood pressure if they are diabetic (Kobos et al. 2020). Loneliness decreases pulse pressure reactivity and increases vascular resistance and lowers the cardiac output (Hawkley \& Cacioppo 2003, Hawkley et al. 2003, O'Donovan et al. 2007). Hawkley and his group estimated that systolic blood pressure in lonely individuals would increase by $3.6 \mathrm{mmHg}$ per year when compared with the least lonely individuals (Hawkley et al. 2010). Diastolic blood pressure elevations are also influenced by acute mental stress in women (Steptoe et al. 2004). Loneliness and social isolation exacerbate atherogenesis in animal studies (Bernberg et al. 2008). In humans, they also impact atherogenesis and are independent risk factors for CVD (Holt-Lunstad \& Smith 2016). Increased coronary artery calcification, a marker of atherosclerosis, has been noted in socially isolated individuals (Kop et al. 2005). In a meta-analysis done in 2016, Valtorta and his group found that in 11 longitudinal studies on cardiovascular diseases, social isolation was associated with 29\% excess risk of incident CHD (Valtorta et al. 2016). Subsequent studies have confirmed that loneliness is associated with an increased risk for CHD (Hakulinen et al. 2018). Lack of social support in patients after a myocardial infarction is also a marker of poor prognosis, with increased readmission, and re-infarction rates, and higher mortality (Glozier et al. 2013). Hakulinen and group found that social isolation was associated with a 1.5fold increased risk of mortality after an acute myocardial infarction (Hakulinen et al. 2018). In patients following coronary artery bypass grafting, verbalizing the term "I feel lonely", increased mortality, both at 30 days and at 5 years after the surgery (Herlitz et al. 1998). In a meta-analysis done by Valtorta and his group, there was a $32 \%$ increase in the relative risk of stroke in individuals with poor social relationships or loneliness across nine independent studies, involving 2577 events (Valtorta et al. 2016). Lonely individuals experience poor recovery and greater functional decline following a stroke (Boden-Albala et al. 2005). They also have a higher risk of recurrent stroke and greater disability (Boden-Albala et al. 2005). On the other hand, stroke patients with high levels of social support or large social networks have a more rapid and extensive functional recovery after the event (Boden-Albala et al. 2005). Stroke patients suffer from several impairments (Hilari et al. 2010, Theeke et al. 2014) and it is not surprising that they face increased depression (Jongenelis et al. 2004) and loneliness (Ebrahim et al. 1987). This leads to a further decrease in theit quality of life (Theeke et al. 2012). Women who are widowed or unmarried and living alone are 3.5 times more likely to be institutionalized following a stroke (Petrea et al. 2009). Lonely stroke individuals also suffer from increased mortality (Tilvis et al. 2011). Loneliness is common in heart failure patients (Löfvenmark et al. 2009). They experience more dyspnea, and greater dyspnea with lower social support (Seo et al. 2014). They also have more depression (Brouwers et al. 2014). They are more likely to visit the emergency room and have an increased risk of hospitalization (NASEM, 2020). Lonely heart failure patients end up spending more days in the hospital and are more likely to get readmitted (Löfvenmark et al. 2009). They tend to be less compliant with health care recommendations, especially those given for regular exercise, daily weighing, and restricted sodium intake (Jankowska-Polańska et al. 2020). Women with loneliness and heart failure experience a poorer quality of life (Burström et al. 2012). Lonely heart failure patients also over-utilize healthcare resources (Löfvenmark et al. 2009). Loneliness is associated with a nearly 4 times increased risk of death in these patients (NASEM, 2020). Loneliness-induced psychosomatic stress also increases the risk of sudden cardiac death (Kuller et al. 1987, Palacios-Ceña et al. 2018).

Loneliness deleteriously impacts CVds by unfavorably affecting some major risk factors, primarily due to a poor compliance with healthy lifestyles by these individuals (Richard et al. 2017, Hackett et al. 2020). Major risk factors affected by poor lifestyles include dyslipidemia (Vargas et al. 2016, Richard et al. 2017, Floyd et al. 2017), diabetes mellitus (Lukaschek et al. 2017, Hackett et al. 2020), chronic kidney disease (Moorthi \& Latham-Mintus 2019), metabolic syndrome (Henriksen et al. 2019, Kim et al. 2020), obesity (Rotenberg et al. 2017), psychosomatic stress (An et al. 2016), depression (Stickley et al. 2016, Matthews et al. 2016), and inadequate restorative sleep (Cacioppo et al. 2002)

Social isolation in rat pups subjected to periodic maternal separation has been associated with dyslipidemia (Vargas et al. 2016). Loneliness has also been linked with high cholesterol levels in humans (Richard et al. 2017). Individuals with higher social inclusion have lower low-density lipoprotein cholesterol levels (Floyd et al. 2018). Proper diet, physical activity, and desirable body weight greatly influence the lipid levels, and lonely individuals tend to be more non-compliant with these (Sorace et al. 2006). Loneliness is a risk factor for type 2 diabetes, both in animals (Nonogaki et al. 2007) and humans (Lukaschek et al. 2017). This link between loneliness and diabetes appears to be independent of other confounding factors, such as age, sex, ethnicity, wealth, smoking status, physical activity, alcohol intake, body mass index, HbA1c, hypertension, and known CVD (Hackett et al. 2020). Studies have demonstrated decreased social participation in adults with pre-dialysis chronic kidney disease (CKD) (Moorthi \& Latham-Mintus 2019), those undergoing dialysis (Meltzer et al. 1989), and transplant recipients (Bailey et al. 2018). Smoking (Jo et al. 2020), drinking alcohol (Shankar et al. 2006). and obesity (Kovesdy et al. 2017) are reversible lifestyle factors that affect CKD and are more common in lonely individuals. Loneliness is also associated with metabolic syndrome (Whisman 2010). After analyzing data from the 'Nord-Trøndelag Health Study' involving 26,990 individuals followed for ten years, Henriksen and his group reported that individuals with higher levels of loneliness had a higher odd of developing metabolic syndrome (Henriksen et al. 2019). In a recently published study, metabolic syndrome was more common in individuals with a smaller social network (Kim et al. 2020). Social isolation in animals promotes the development of obesity (Nonogaki et al. 2007). In humans, lonely people tend to be more obese than non-lonely people (Lauder et al. 2006), and this is more prominent in older men (Hajek \& König. 2019). Obesity further leads to more loneliness (Rotenberg et al. 2019). Behavioral modifications leading to a weight loss (as little as $\geq 5 \%$ 
initial weight) among individuals with overweight/obesity improve several risk factors for CVD ( LeBlanc et al. 2018). Low social support also results in chronic stress in adults (Steptoe \& Kivimaki 2013). Loneliness is intricately associated with depression (Jaremka et al. 2014). This association has been seen in children (Qualter et al. 2010), adolescents (Stickley et al. 2016), young adults (Matthews et al. 2016), and older adults (Nyqvist et al. 2019). It prognosticates a worse course in these individuals with CVD (Ziggi et al. 2016). Loneliness is associated with poorer sleep quality, and the latter correlates negatively with CVD (Cacioppo et al. 2002, Hawkley et al. 2010). Depression in these individuals (Matthews et al. 2016), further aggravates sleep disorders (Wang et al. 2015). Diminished social support is associated with increased CVD morbidity (An et al. 2016). In a study by Barth and group, cardiac and all-cause mortality was 1.6-fold higher in patients with low social support (Barth et al. 2010).

\subsection{Mechanisms behind the harmful CVD effects of loneliness}

Loneliness and social isolation activate the hypothalamic-pituitary-adrenal (HPA) axis (Cacioppo \& Cacioppo 2015). resulting in higher cortisol levels (Doane \& Adam 2010) and a flattened diurnal cortisol slope (Zilioli et al. 2017). Cortisol, the final product in the HPA axis chain, is characterized by a distinctive diurnal patterning, with concentrations highest in the mornings and progressively declining over the day (Adam \& Kumari 2009). HPA axis dysfunction (Rosmond \& Björntorp et al. 2000), abnormally high cortisol or a disturbed circadian rhythm are all associated with CVD (Crawford et al 2019). Loneliness also leads to an enhanced sympathetic nerve activity and an impaired parasympathetic function (McNeal et al. 2014). Loneliness in rats leads to increases in the plasma concentrations of both epinephrine and norepinephrine (Gavrilovi et al. 2010). Sustained activation of the sympathetic adrenal medullary system resulting in overexposure to epinephrine and norepinephrine contributes to the development of CVD (Lundberg 1999). Loneliness also raises the levels of three systemic inflammation biomarkers (Nersesian et al. 2018), interleukin-6, fibrinogen, and C-reactive protein (Smith et al. 2020). Studies have found alterations in inflammatory gene expression (Powell et al. 2013), with genes responsible for anti-inflammatory glucocorticoid response elements being under-expressed, and genes bearing response elements for pro-inflammatory NF- $\mathrm{BB} / \mathrm{Rel}$ transcription factors, being over-expressed (Cole et al. 2007). Chronic inflammation plays a key role in all phases of CVD (Ross 1999). Loneliness also decreases immunity (Walker et al. 2019). Immunity, both innate and adaptive, is actively involved in atherogenesis (Frostegård et al. 2013). Loneliness also reduces healthy lifestyles. Lonely people have reduced self-regulation (Hawkley \& Cacioppo 2010) and tend to lead unhealthy lifestyles (Shankar et al. 2011, Algren et al. 2020). On the other hand, individuals with stronger social connections are more likely to practice healthy lifestyles (Samuel et al. 2015). Lonely individuals are more likely to be non-compliant with recommended physical activity (Shiovitz-Ezra \& Litwin 2012), follow an unhealthy diet (Locher et al. 2005), be overweight or obese (Whisman 2010), indulge in high alcohol intake (Shiovitz-Ezra \& Litwin 2012), or smoke (Christakis \& Fowler 2008). This is despite being aware of the documented benefits of healthier lifestyles on cardiovascular diseases (Perk et al. 2012). On the other hand, a good social support system results in decreased loneliness and much healthier lifestyles (Debnam et al. 2012). Lonely people often lack support from social networks, family members and neighbors and may also be non-compliant in accessing health care services or following treatment recommendations (Jankowska-Polańska et al. 2020). Unknown factors, such as genetic polymorphism may also play a role in the loneliness and its CVD connection.

\subsection{Therapeutic interventions}

Several therapeutic interventions have been developed to treat loneliness and include antidepressants, neuro-steroids, and oxytocin (Masi et al. 2010). Cognitive-behavioral therapy has shown to be beneficial in lonely individuals (Theeke et al. 2016). Multimodal behavioral interventions involving nutrition, physical activity, weight management, alcohol moderation, smoking cessation, and relaxation training, via healthcare counseling can also help promote healthy lifestyles in lonely individuals (Artinian et al. 2010).

\section{Conclusion}

The data is extremely persuasive regarding the ill effects exerted by social isolation and loneliness on cardiovascular morbidity and mortality. With the increasing prevalence of loneliness and the continuing harmful impact of cardiovascular diseases globally, it is imperative that this connection be recognized, and multimodal behavioral interventions aimed at reducing the ill effects of the former, are instituted. Given its significant effect on cardiovascular diseases, which may be comparable to those conveyed by smoking, obesity, and hypertension, loneliness should be considered as and labeled as a major risk factor for CVD. Besides the potential reduction in CVD, therapeutic interventions for loneliness should also help reduce several other chronic diseases and improve the quality of life in these patients.

\section{Acknowledgements}

None

\section{Funding}

None

\section{Conflict of interest}




\section{References}

[1] Adam, E. K., \& Kumari, M. (2009). Assessing salivary cortisol in large-scale, epidemiological research. Psychoneuroendocrinology, 34(10), 14231436. https://doi.org/10.1016/j.psyneuen.2009.06.011.

[2] Aguilar M, Bhuket T, Torres S, Liu B, Wong RJ. Prevalence of the Metabolic Syndrome in the United States, 2003-2012. JAMA. 2015;313(19):19731974. https://doi.org/10.1001/jama.2015.4260.

[3] Akerlind I, Hörnquist JO. Loneliness and alcohol abuse: a review of evidences of an interplay. Social Science \& Medicine. 1992;34:405-414. https://doi.org/10.1016/0277-9536(92)90300-F

[4] Akerlind I, Hörnquist E, Muula AS, Siziya S, Twa-Twa J. Suicidal ideation and associated factors among school-going adolescents in rural Uganda. BMC Psychiatry. 2007;7:67. https://doi.org/10.1186/1471-244X-7-67.

[5] Algren MH, Ekholm O, Nielsen L, Ersbøll AK, Bak CK, Andersen PT. Social isolation, loneliness, socioeconomic status, and health-risk behaviour in deprived neighbourhoods in Denmark: A cross-sectional study. SSM Popul Health. 2020;10:100546. Published 2020 Jan 20. https://doi.org/10.1016/j.ssmph.2020.100546.

[6] An K, Salyer J, Brown RE, Kao HF, Starkweather A, Shim I. Salivary Biomarkers of Chronic Psychosocial Stress and CVD Risks: A Systematic Review. Biol Res Nurs. 2016 May;18(3):241-63. https://doi.org/10.1177/1099800415604437.

[7] Artinian NT, Fletcher GF, Mozaffarian D, et al.. Interventions to promote physical activity and dietary lifestyle changes for cardiovascular risk factor reduction in adults: a scientific statement from the American Heart Association. Circulation 2010;122:406-441. https://doi.org/10.1161/CIR.0b013e3181e8edf1.

[8] Asad Z, Abbas M, Javed I, et al. Obesity is associated with incident atrial fibrillation independent of gender: a meta-analysis. J Cardiovasc Electrophysiol. 2018;29:725-32. https://doi.org/10.1111/jce.13458.

[9] Asher S, Hymel S, Renshaw PD. Loneliness in children. Child Development. 1984;55:1456-1464. https://doi.org/10.2307/1130015.

[10] Barth J, Schneider S, von Känel R. Lack of social support in the etiology and the prognosis of coronary heart disease: a systematic review and metaanalysis. Psychosom Med. 2010;72(3):229-38. https://doi.org/10.1097/PSY.0b013e3181d01611.

[11] Bailey PK, Hamilton AJ, Clissold RL. et al. Young adults' perspectives on living with kidney failure: a systematic review and thematic synthesis of qualitative studies. BMJ Open 2018; 8: e019926. https://doi.org/10.1136/bmjopen-2017-019926.

[12] Benjamin E. J., Muntner P., Alonso A., Bittencourt M. S., Callaway C. W., Carson A. P., et al. (2019). Heart Disease and Stroke Statistics-2019 Update: A Report From the American Heart Association. Circulation 139 (10), e56-e528. https://doi.org/10.1161/CIR.0000000000000659.

[13] Bernberg E., I.J. Andersson, L.M. Gan, A.S. Naylor, M.E. Johansson, G. Bergstrom. Effects of social isolation and environmental enrichment on atherosclerosis in ApoE-/- mice. Stress, 11 (5) (2008), pp. 381-389. https://doi.org/10.1080/10253890701824051.

[14] Blumenthal JA et al. Depression as a risk factor for poor prognosis among patients with acute coronary syndrome: systematic review and recommendations: a scientific statement from the American Heart Association. Circulation 2014; 129: 1350-69. https://doi.org/10.1161/CIR.0000000000000019.

[15] Boden-Albala B, Litwak E, Elkind M, Rundek T, Sacco R. Social isolation and outcomes post stroke. Neurology. 2005;64:1888-92. https://doi.org/10.1212/01.WNL.0000163510.79351.AF.

[16] Boyle JP, Thompson TJ, Gregg EW, Barker LE, Williamson DF. Projection of the year 2050 burden of diabetes in the US adult population: dynamic modeling of incidence, mortality, and prediabetes prevalence. Popul Health Metr 2010;8:29. https://doi.org/10.1186/1478-7954-8-29.

[17] Brandt EJ, Myerson R, Perraillon MC, et al. Hospital admissions for myocardial infarction and stroke before and after the trans-fatty acid restrictions in New York. JAMA Cardiol. 2017;2:627-34. https://doi.org/10.1001/jamacardio.2017.0491.

[18] Brouwers C, Kupper N, Pelle AJ, Szabo BM, Westerhuis BL, Denollet J. Depressive symptoms in outpatients with heart failure: Importance of inflammatory biomarkers, disease severity and personality. Psychol Health. 2014;29:564-82. https://doi.org/10.1080/08870446.2013.869813.

[19] Bundy JD, Mills KT, Cheng J, et al. Estimating the association of the 2017 and 2014 hypertension guidelines with cardiovascular events and deaths in US adults: An analysis of national data. JAMA Cardiol 2018 May 23 https://doi.org/10.1001/jamacardio.2018.1240.

[20] Burström M, Brännström M, Boman K, Strandberg G. Life experiences of security and insecurity among women with chronic heart failure. J Adv Nurs. 2012 Apr;68(4):816-25. https://doi.org/10.1111/j.1365-2648.2011.05782.x.

[21] Cacioppo S. and Cacioppo JT. Why may allopregnanolone help alleviate loneliness? Med Hypotheses 85: 947-952, 2015. https://doi.org/10.1016/j.mehy.2015.09.004.

[22] Cacioppo S, Capitanio JP, Cacioppo JT. Toward a neurology of loneliness. Psychological Bulletin. 2014 https://doi.org/10.1037/a0037618.

[23] Cacioppo JT, Hawkley LC. People thinking about people: The vicious cycle of being a social outcast in one's own mind. In: Williams KD, Forgas JP, von Hippel W, editors. The social outcast: Ostracism, social exclusion, rejection, and bullying. New York: Psychology Press; 2005. pp. 91-108.

[24] Cacioppo JT, Hawkley LC, Berntson GG, Ernst JM, Gibbs AC, Stickgold R, Hobson J (2002). Do lonely days invade the nights? Potential social modulation of sleep efficiency. Psychological Science 13, 384-387. https://doi.org/10.1111/j.0956-7976.2002.00469.x.

[25] Cacioppo JT, Hawkley LC, Thisted RA. Perceived social isolation makes me sad: Five year cross-lagged analyses of loneliness and depressive symptomatology in the Chicago Health, Aging, and Social Relations Study. Psychology and Aging. 2010;25:453-463. https://doi.org/10.1037/a0017216.

[26] Carroll M.D., Fryer C.D., Nguyen D.T. High Total and Low High-Density Lipoprotein Cholesterol in Adults: United States, 2015-2016. National Center for Health Statistics; Hyattsville, MD, USA: 2017.

[27] Cassidy J, Asher SR. Loneliness and peer relations in young children. Child Development. 1992;63(2):350-365. https://doi.org/10.2307/1131484.

[28] CDC. Centers for Disease Control and Prevention: Chronic Kidney Disease Surveillance System-United States, 2018. Available at http://www.cdc.gov/ckd. Accessed October 29, 2020.

[29] CDC. National Center for Health Statistics. National Health and Nutrition Examination Survey (NHANES) public use data files. Centers for Disease Control and Prevention website. https://www.cdc.gov/nchs/nhanes/. Accessed April 1, 2019.

[30] Cheng S, Claggett B, Correia AW, et al. Temporal trends in the population attributable risk for cardiovascular disease: The Atherosclerosis Risk in Communities Study. Circulation 2014;130:820-828. https://doi.org/10.1161/CIRCULATIONAHA.113.008506.

[31] Christakis NA, Fowler JH. The collective dynamics of smoking in a large social network. N Engl J Med. 2008; 358(21): 2249-2258. https://doi.org/10.1056/NEJMsa0706154.

[32] Cigna/Ipsos. 2018. Cigna U.S. loneliness index. https://www.cigna.com/about-us/newsroom/studies-and-reports/combatting-loneliness/ (accessed July 28, 2020)

[33] Cole SW, Hawkley LC, Arevalo JM, Sung CY, Rose RM, Cacioppo JT. Social regulation of gene expression in human leukocytes. Genome Biology. 2007;8(9): R189.181-R189.113. https://doi.org/10.1186/gb-2007-8-9-r189.

[34] Craig M. Hales, Margaret D. Carroll, Cheryl D. Fryar, and Cynthia L. Ogden. Prevalence of Obesity and Severe Obesity Among Adults: United States, 2017-2018. NCHS Data Brief No. 360, February 2020.

[35] Crawford AA, Soderberg S, Kirschbaum C, et al. Morning plasma cortisol as a cardiovascular risk factor: findings from prospective cohort and Mendelian randomization studies. Eur J Endocrinol. 2019;181(4):429-438. https://doi.org/10.1530/EJE-19-0161.

[36] Danaei G, Ding EL, Mozaffarian D, et al. The preventable causes of death in the United States: Comparative risk assessment of dietary, lifestyle, and metabolic risk factors. PLoS Med 2009;6:e1000058. https://doi.org/10.1371/journal.pmed.1000058.

[37] Debnam K, Holt CL, Clark EM, Roth DL, Southward P. Relationship between religious social support and general social support with health behaviors in a national sample of African Americans. Journal of Behavioral Medicine. 2012;35(2):179-189. https://doi.org/10.1007/s10865-0119338-4. 
[38] De Jong Gierveld J, van Tilburg T. Living arrangements of older adults in the Netherlands and Italy: Coresidence values and behaviour and their consequences for loneliness. Journal of Cross-Cultural Gerontology. 1999;14(1):1-24. https://doi.org/10.1023/A:1006600825693.

[39] Dickens CM, McGowan L, Percival C, Tomenson B, Cotter L, Heagerty A, Creed FH. Contribution of distress and anxiety to impaired health-related quality of life following first myocardial infarction. Br J Psychiatry. 2006;189:367-372. https://doi.org/10.1192/bjp.bp.105.018234.

[40] Doane LD, Adam EK. Loneliness and cortisol: momentary, day-to-day, and trait associations. Psychoneuroendocrinology. $2010 ; 35(3): 430-441$. https://doi.org/10.1016/j.psyneuen.2009.08.005.

[41] Drageset J, Eide GE, Kirkevold M, Ranhoff AH. Emotional loneliness is associated with mortality among mentally intact nursing home residents with and without cancer: A five-year follow-up study. Journal of Clinical Nursing. 2013;22(1-2):106-114. https://doi.org/10.1111/j.13652702.2012.04209.x.

[42] Ebrahim S, Barer D, Nouri F. Affective illness after stroke. Br J Psychiatry. 1987;151:52-6. https://doi.org/10.1192/bjp.151.1.52.

[43] Einarson TR, Acs A, Ludwig C, et al. Prevalence of cardiovascular disease in type 2 diabetes: a systematic literature review of scientific evidence from across the world in 2007-2017. Cardiovasc Diabetol 2018;17:83. https://doi.org/10.1186/s12933-018-0728-6.

[44] Ekelund U, Steene-Johannessen J, Brown WJ, et al. Does physical activity attenuate, or even eliminate, the detrimental association of sitting time with mortality? A harmonised meta-analysis of data from more than 1 million men and women. Lancet. 2016;388:1302-10. https://doi.org/10.1016/S0140-6736(16)30370-1.

[45] Erhardt L. Cigarette smoking: an undertreated risk factor for cardiovascular disease. Atherosclerosis. 2009; 205: 23-32. https://doi.org/10.1016/j.atherosclerosis.2009.01.007.

[46] Gavrilovi L, N. Spasojevic, S. Dronjak. Chronic individual housing-induced stress decreased expression of catecholamine biosynthetic enzyme genes and proteins in spleen of adult rats. Neuroimmunomodulation, 17 (4) (2010), pp. 265-269. https://doi.org/10.1159/000290042.

[47] Floyd K, Veksler AE, McEwan B, Hesse C, Boren JP, Dinsmore DR, Pavlich CA. Social Inclusion Predicts Lower Blood Glucose and Low-Density Lipoproteins in Healthy Adults. Health Commun. 2017 Aug;32(8):1039-1042. https://doi.org/10.1080/10410236.2016.1196423.

[48] Frostegård J. Immunity, atherosclerosis and cardiovascular disease. BMC Med. 2013 May 1;11:117. https://doi.org/10.1186/1741-7015-11-117.

[49] Gami AS, Witt BJ, Howard DE, Erwin PJ, Gami LA, Somers VK, Montori VM. Metabolic syndrome and risk of incident cardiovascular events and death: a systematic review and meta-analysis of longitudinal studies. J Am Coll Cardiol. 2007 Jan 30;49(4):403-14. https://doi.org/10.1016/j.jacc.2006.09.032.

[50] Gan Y, Gong Y, Tong X, et al. . Depression and the risk of coronary heart disease: a meta-analysis of prospective cohort studies. BMC Psychiatry. 2014;14:371. https://doi.org/10.1186/s12888-014-0371-Z.

[51] Gandhi S, Goodman SG, Greenlaw N, Ford I, McSkimming P, Ferrari R, Jang Y, Alcocer-Gamba MA, Fox K, Tardif JC, Tendera M, Dorian P, Steg G, Udell JA. Living alone and cardiovascular disease outcomes. Heart. 2019 Jul;105(14):1087-1095. https://doi.org/10.1136/heartjnl-2018-313844.

[52] Glozier, N., G. H. Tofler, D. M. Colquhoun, et al. 2013. Psychosocial risk factors for coronary heart disease. Medical Journal of Australia 199(3):179180. https://doi.org/10.5694/mja13.10440.

[53] Go AS, Mozaffarian D, Roger VL, et al. Heart disease and stroke statistics--2014 update: a report from the American Heart Association. Circulation. 2014;129(3):e28-e292. https://doi.org/10.1161/01.cir.0000441139.02102.80.

[54] Hackett RA, Hudson JL, Chilcot J. Loneliness and type 2 diabetes incidence: findings from the English Longitudinal Study of Ageing. Diabetologia. 2020;63(11):2329-2338. https://doi.org/10.1007/s00125-020-05258-6.

[55] Hakulinen, C., L. Pulkki-Råback, M. Virtanen, M. Jokela, M. Kivimäki, and M. Elovainio. 2018. Social isolation and loneliness as risk factors for myocardial infarction, stroke and mortality: UK Biobank cohort study of 479,054 men and women. Heart 104(18):1536-1542. https://doi.org/10.1136/heartjnl-2017-312663.

[56] Hajek A, König HH. Obesity and loneliness. Findings from a longitudinal population-based study in the second half of life in Germany. Psychogeriatrics. 2019 Mar;19(2):135-140. https://doi.org/10.1111/psyg.12375.

[57] Hansson GK. Inflammation, atherosclerosis, and coronary artery disease. N Engl J Med. 2005 Apr 21;352(16):1685-95. https://doi.org/10.1056/NEJMra043430.

[58] Hawkley LC, Burleson MH, Berntson GG, Cacioppo JT. Loneliness in everyday life: cardiovascular activity, psychosocial context, and health behaviors. J Pers Soc Psychol. 2003 Jul;85(1):105-20. https://doi.org/10.1037/0022-3514.85.1.105.

[59] Hawkley LC, Cacioppo JT. Loneliness and pathways to disease. Brain Behav Immun. 2003;17 Suppl 1:S98-S105. https://doi.org/10.1016/S08891591(02)00073-9.

[60] Hawkley LC, Cacioppo JT. Loneliness matters: a theoretical and empirical review of consequences and mechanisms. Ann Behav Med. 2010;40(2):218-27. https://doi.org/10.1007/s12160-010-9210-8.

[61] Hawkley LC, Masi CM, Berry JD, and Cacioppo JT. Loneliness is a unique predictor of age-related differences in systolic blood pressure. Psychol Aging 21: 152-164, 2006. https://doi.org/10.1037/0882-7974.21.1.152.

[62] Hawkley LC, Preacher KJ, Cacioppo JT (2010a). Loneliness impairs daytime functioning but not sleep duration. Health Psychology 29, 124-129 https://doi.org/10.1037/a0018646.

[63] Hawkley LC, Thisted RA, Masi CM, and Cacioppo JT. Loneliness predicts increased blood pressure: 5-year cross-lagged analyses in middle-aged and older adults. Psychol Aging 25: 132-141, 2010. https://doi.org/10.1037/a0017805.

[64] Healthline.com available at https://www.healthline.com/health/heart-disease/statistics - accessed October 18, 2020.

[65] Heidenreich PA, Albert NM, Allen LA, Bluemke DA, Butler J, Fonarow GC, Ikonomidis JS, Khavjou O, Konstam MA, Maddox TM, et al.; on behalf of the American Heart Association Advocacy Coordinating Committee; Council on Arteriosclerosis, Thrombosis and Vascular Biology; Council on Cardiovascular Radiology and Intervention; Council on Clinical Cardiology; Council on Epidemiology and Prevention; Stroke Council. Forecasting the impact of heart failure in the United States: a policy statement from the American Heart Association.Circ Heart Fail. 2013; 6:606619. https://doi.org/10.1161/HHF.0b013e318291329a.

[66] Heinrich LM, Gullone E. The clinical significance of loneliness: a literature review. Clin Psychol Rev. 2006;26(6):695-718. https://doi.org/10.1016/j.cpr.2006.04.002.

[67] Henriksen RE, Nilsen RM, Strandberg RB. Loneliness as a risk factor for metabolic syndrome: results from the HUNT study. J Epidemiol Community Health. 2019 Oct;73(10):941-946. https://doi.org/10.1136/jech-2019-212335.

[68] Herlitz J, Wiklund I, Caidahl K, Hartford M, Haglid M, Karlsson BW, Sjöland H, Karlsson T. The feeling of loneliness prior to coronary artery bypass grafting might be a predictor of short-and long-term postoperative mortality. Eur J Vasc Endovasc Surg. 1998 Aug;16(2):120-5. https://doi.org/10.1016/S1078-5884(98)80152-4.

[69] Hilari K, Northcott S, Roy P, et al. Psychological distress after stroke and aphasia: the first six months. Clin Rehabil. 2010;24:181-90. https://doi.org/10.1177/0269215509346090.

[70] Holt-Lunstad J, Smith TB, Baker M, Harris T, and Stephenson D. Loneliness and social isolation as risk factors for mortality: a meta-analytic review. Perspect Psychol Sci 10: 227-237, 2015. https://doi.org/10.1177/1745691614568352.

[71] Holt-Lunstad J, Smith TB, and Layton JB. Social relationships and mortality risk: a meta-analytic review. PLoS Med 7: e1000316, 2010. https://doi.org/10.1371/journal.pmed.1000316.

[72] Holt-Lunstad J, Smith T.B. Loneliness and social isolation as risk factors for CVD: implications for evidence-based patient care and scientific inquiry. Heart, 102 (13) (2016), pp. 987-989. https://doi.org/10.1136/heartjnl-2015-309242.

[73] Jankowska-Polańska B, Swiątoniowska-Lonc N, Sławuta A, Krówczyńska D, Dudek K, Mazur G. Patient-Reported Compliance in older age patients with chronic heart failure. PLoS One. 2020 Apr 16;15(4):e0231076. https://doi.org/10.1371/journal.pone.0231076. 
[74] Jaremka LM, Andridge RR, Fagundes CP, Alfano CM, Povoski SP, Lipari AM, et al. Pain, depression, and fatigue: loneliness as a longitudinal risk factor. Health Psychol. 2014;33(9):948-57. https://doi.org/10.1037/a0034012.

[75] Jo W, Lee S, Joo YS, et al. Association of smoking with incident CKD risk in the general population: A community-based cohort study. PLoS One. 2020 Aug 27;15(8):e0238111. https://doi.org/10.1371/journal.pone.0238111.

[76] Jongenelis J. K, Pot A, Eisses A, Beekman A, Kluiter H, Ribbe M. Prevalence and risk indicators of depression in elderly nursing home patients: The aged study. J Affect Disord. 2004;83:135-42. https://doi.org/10.1016/j.jad.2004.06.001

[77] Jung FU, Luck-Sikorski C. Overweight and Lonely? A Representative Study on Loneliness in Obese People and Its Determinants. Obes Facts. 2019;12(4):440-447. https://doi.org/10.1159/000500095.

[78] Kim K, Jung SJ, Baek JM, et al. Associations between social network properties and metabolic syndrome and the mediating effect of physical activity: findings from the Cardiovascular and Metabolic Diseases Etiology Research Center (CMERC) CohortBMJ Open Diabetes Research and Care 2020;8:e001272. https://doi.org/10.1136/bmjdrc-2020-001272.

[79] King CR, Knutson KL, Rathouz PJ, Sidney S, Liu K, Lauderdale DS. Short sleep duration and incident coronary artery calcification. JAMA. 2008;300:2859-66. https://doi.org/10.1001/jama.2008.867.

[80] Kobos E, Szewczyk A, Świątkowska T, Kryczka T, Sienkiewicz Z. Relationship between loneliness and blood glucose control in diabetes. BMC Public Health. 2020 Jul 20;20(1):1140. https://doi.org/10.1186/s12889-020-09241-Z.

[81] Kop WJ, Berman DS, Gransar H, Wong ND, Miranda-Peats R, White MD, Shin M, Bruce M, Krantz DS, Rozanski A. Social network and coronary artery calcification in asymptomatic individuals. Psychosom Med. 2005;37:343-52. https://doi.org/10.1097/01.psy.0000161201.45643.8d

[82] Kovesdy CP, Furth SL, Zoccali C; World Kidney Day Steering Committee. Obesity and kidney disease: hidden consequences of the epidemic. J Ren Nutr. 2017;27(2):75-77. https://doi.org/10.1053/j.jrn.2017.01.001

[83] Kuller LH, Talbott EO, Robinson C. Environmental and psychosocial determinants of sudden death. Circulation. 1987 Jul;76(1 Pt 2):I177-85.

[84] Lauder W, Mummery K, Jones M, Caperchione C. A comparison of health behaviours in lonely and non-lonely populations. Psychol Health Med. 2006;11(2):233-45. https://doi.org/10.1080/13548500500266607.

[85] LeBlanc EL, Patnode CD, Webber EM, et al. Draft evidence review for weight loss to prevent obesityrelated morbidity and mortality in adults: behavioral interventions. Kaiser Permanente Research Affiliates Evidence-based Practice Center, Kaiser Permanente Center for Health Research: Portland, OR; 2018. AHRQ Publication No. 18-05239-EF-1.

[86] Liu L, Liu C, Wang Y, Wang P, Li Y, Li B. Herbal Medicine for Anxiety, Depression and Insomnia. Curr Neuropharmacol. 2015;13(4):481-493. https://doi.org/10.2174/1570159X1304150831122734.

[87] Locher JL, Ritchie CS, Roth DL, Baker PS, Bodner EV, Allman RM. Social isolation, support, and capital and nutritional risk in an older sample: Ethnic and gender differences. Soc Sci Med. 2005; 60(4): 747-761. https://doi.org/10.1016/j.socscimed.2004.06.023.

[88] Löfvenmark C, Mattiasson AC, Billing E, Edner M. Perceived loneliness and social support in patients with chronic heart failure. Eur J Cardiovasc Nurs. 2009 Oct;8(4):251-8. https://doi.org/10.1016/j.ejcnurse.2009.05.001.

[89] Lukaschek K, Baumert J, Kruse J, Meisinger C, Ladwig KH. Sex differences in the association of social network satisfaction and the risk for type 2 diabetes. BMC Public Health. 2017;17(1):379. https://doi.org/10.1186/s12889-017-4323-7.

[90] Lundberg U. Coping with Stress: Neuroendocrine Reactions and Implications for Health. Noise Health. 1999;1(4):67-74.

[91] Madsen KR, Holstein BE, Damsgaard MT, Rayce SB, Jespersen LN, Due P. Trends in social inequality in loneliness among adolescents $1991-2014$. J Public Health (Oxf). 2019 Jun 1;41(2):e133-e140. https://doi.org/10.1093/pubmed/fdy133.

[92] Masi CM, Chen HY, Hawkley LC, Cacioppo JT. A meta-analysis of interventions to reduce loneliness. Personality and Social Psychology Review. 2010;15:219-266. https://doi.org/10.1177/1088868310377394.

[93] Matthews T, Danese A, Wertz J, Odgers CL, Ambler A, Moffitt TE, et al. Social isolation, loneliness and depression in young adulthood: a behavioural genetic analysis. Soc Psychiatry Psychiatr Epidemiol. 2016;51(3):339-48. https://doi.org/10.1007/s00127-016-1178-7.

[94] McNeal N, M.A. Scotti, J. Wardwell, D.L. Chandler, S.L. Bates, M. Larocca, D.M. Trahanas, A.J. Grippo. Disruption of social bonds induces behavioral and physiological dysregulation in male and female prairie voles .Auton. Neurosci., 180 (2014), pp. 9-16J.T. https://doi.org/10.1016/j.autneu.2013.10.001.

[95] Melzer SM, Leadbeater B, Reisman L. et al. Characteristics of social networks in adolescents with end-stage renal disease treated with renal transplantation. J Adolesc Health Care 1989; 10: 308-312. https://doi.org/10.1016/0197-0070(89)90063-6.

[96] Moorthi RN, Latham-Mintus K. Social isolation in chronic kidney disease and the role of mobility limitation. Clin Kidney J. 2019;12(4):602-610. Published 2019 Jan 14. https://doi.org/10.1093/ckj/sfy134.

[97] Mottillo S, Filion KB, Genest J, Joseph L, Pilote L, Poirier P, Rinfret S, Schiffrin EL, Eisenberg MJ. The metabolic syndrome and cardiovascular risk a systematic review and meta-analysis. J Am Coll Cardiol. 2010 Sep 28;56(14):1113-32. https://doi.org/10.1016/j.jacc.2010.05.034

[98] Mozaffarian D, E. J. Benjamin, A. S. Go, D. K. Arnett, M. J. Blaha, and M. Cushman, "Heart Disease and Stroke Statistics-2016 Update: A Report from the American Heart Association," Circulation, vol. 133, no. 4, pp. e38-360, 2016.

[99] Nabi H, Kivimaki M, Batty GD, Shipley MJ, Britton A, Brunner EJ, et al. Increased risk of coronary heart disease among individuals reporting adverse impact of stress on their health: the Whitehall II prospective cohort study. Eur Heart J. 2013;34(34):2697-705. https://doi.org/10.1093/eurheartj/eht216.

[100] NASEM. National Academies of Sciences, Engineering, and Medicine. 2020. Social Isolation and Loneliness in Older Adults: Opportunities for the Health Care System. Washington, DC: The National Academies Press.

[101] Nersesian, P. V. , Han, H.-R. , Yenokyan, G. , Blumenthal, R. S. , Nolan, M. T. , Hladek, M. D. , \& Szanton, S. L. (2018). Loneliness in middle age and biomarkers of systemic inflammation: Findings from Midlife in the United States. Social Science \& Medicine, 209, 174-181. https://doi.org/10.1016/j.socscimed.2018.04.007.

[102] Nonogaki K, Nozue K, Oka Y. Social isolation affects the development of obesity and type 2 diabetes in mice. Endocrinology. 2007;148(10):4658-66. https://doi.org/10.1210/en.2007-0296.

[103] Nyqvist, F., Nygård, M. \& Scharf, T. Loneliness amongst older people in Europe: a comparative study of welfare regimes. Eur J Ageing 16, 133-143 (2019). https://doi.org/10.1007/s10433-018-0487-y.

[104] O'Donovan A, Hughes B. Social support and loneliness in college students: effects on pulse pressure reactivity to acute stress. Int J Adolesc Med Health. 2007 Oct-Dec;19(4):523-8. https://doi.org/10.1515/IJAMH.2007.19.4.523.

[105] Ovbiagele B, Goldstein LB, Higashida RT, et al. Forecasting the future of stroke in the United States. Stroke 2013;44:2361-75. https://doi.org/10.1161/STR.0b013e31829734f2.

[106] Palacios-Ceña D, Losa-Iglesias ME, Salvadores-Fuentes P, Fernández-de-las-Peñas C. Sudden cardiac death: the perspectives of Spanish survivors. Nurs Health Sci. 2011 Jun;13(2):149-55. https://doi.org/10.1111/j.1442-2018.2011.00593.x.

[107] Perk J, De Backer G, Gohlke H, et al. European Guidelines on cardiovascular disease prevention in clinical practice (version 2012). Eur Heart J 2012; 33: 1635-1701. https://www.cdc.gov/tobacco/data_statistics/sgr/50th-anniversary/pdfs/fs_smoking_CVD_508.pdf. Accessed June 1, 2019

[108] Petrea RE, Beiser AS, Seshadri S, Kelly-Hayes M, Kase CS, Wolf PA. Gender differences in stroke incidence and poststroke disability in the Framingham heart study. Stroke; a journal of cerebral circulation. 2009;40:1032-1037. https://doi.org/10.1161/STROKEAHA.108.542894.

[109] Poole L, Jackowska M. The association between depressive and sleep symptoms for predicting incident disease onset after 6-year follow-up: findings from the English Longitudinal Study of Ageing. Psychol Med. 2019;49(4):607-616. https://doi.org/10.1017/S0033291718001290.

[110] Powell N.D., E.K. Sloan, et al. Social stress up-regulates inflammatory gene expression in the leukocyte transcriptome via beta-adrenergic induction of myelopoiesis.Proc. Natl. Acad. Sci. U.S.A., 110 (41) (2013), pp. 16574-16579. https://doi.org/10.1073/pnas.1310655110

[111] Qualter P, Brown SL, Munn P, Rotenberg KJ. Childhood loneliness as a predictor of adolescent depressive symptoms: an 8-year longitudinal study. Eur Child Adolesc Psychiatry. 2010;19(6):493-501. https://doi.org/10.1007/s00787-009-0059-y. 
[112] Rats. PLoS One. 2016;11(9):e0162665. Published 2016 Sep 9. https://doi.org/10.1371/journal.pone.0162665.

[113] Richard A, Rohrmann S, Vandeleur CL, Schmid M, Barth J, Eichholzer M. Loneliness is adversely associated with physical and mental health and lifestyle factors: Results from a Swiss national survey. PLoS One. 2017;12(7):e0181442. Published 2017 Jul 17. https://doi.org/10.1371/journal.pone.0181442.

[114] Rico-Uribe LA, Caballero FF, Martín-María N, Cabello M, Ayuso-Mateos JL, Miret M. Association of loneliness with all-cause mortality: a meta-analysis. PLoS One. 2018;13(1):e0190033. https://doi.org/10.1371/journal.pone.0190033.

[115] Rico-Uribe LA, Caballero FF, Olaya B, et al. Loneliness, Social Networks, and Health: A Cross-Sectional Study in Three Countries. PloS one. 2016;11(1):e0145264 https://doi.org/10.1371/journal.pone.0145264.

[116] Roger VL, Go AS, Lloyd-Jones DM, Benjamin EJ, Berry JD, Borden WB, et al. Turner MB. Heart disease and stroke statistics-2012 update: A report from the American Heart Association [comparative study] Circulation. 2012;125(1):e2-e220. https://doi.org/10.1161/CIR.0b013e31823ac046.

[117] Ronksley PE, Brien SE, Turner BJ, Mukamal KJ, Ghali WA. Association of alcohol consumption with selected cardiovascular disease outcomes: a systematic review and meta-analysis. BMJ. 2011;342:d671. Published 2011 Feb 22. https://doi.org/10.1136/bmj.d671.

[118] Rosmond R, Björntorp P. The hypothalamic-pituitary-adrenal axis activity as a predictor of cardiovascular disease, type 2 diabetes and stroke. J Intern Med. 2000 Feb;247(2):188-97. https://doi.org/10.1046/j.1365-2796.2000.00603.x.

[119] Ross R: Atherosclerosis--an inflammatory disease. N Engl J Med, 1999; 340: 115-126. https://doi.org/10.1056/NEJM199901143400207.

[120] Roth GA, Johnson CO, Abate KH, et al. The Burden of Cardiovascular Diseases Among US States, 1990-2016. JAMA Cardiol. 2018 May 1;3(5):375-389. https://doi.org/10.1001/jamacardio.2018.0385.

[121] Sacks FM, Svetkey LP, Vollmer WM, et al. Effects on blood pressure of reduced dietary sodium and the Dietary Approaches to Stop Hypertension (DASH) diet. DASH-Sodium Collaborative Research Group. N Engl J Med. 2001;344:3-10. https://doi.org/10.1056/NEJM200101043440101.

[122] Samuel LJ, Dennison Himmelfarb CR, Szklo M, Seeman TE, Echeverria SE, Diez Roux AV. Social engagement and chronic disease risk behaviors: the Multi-Ethnic Study of Atherosclerosis. Prev Med. 2015;71:61-66. https://doi.org/10.1016/j.ypmed.2014.12.008.

[123] Sattelmair J, Pertman J, Ding EL, et al. Dose response between physical activity and risk of coronary heart disease: a meta-analysis. Circulation. 2011;124:789-95. https://doi.org/10.1161/CIRCULATIONAHA.110.010710.

[124] Schrier R.W. Cardiorenal versus renocardiac syndrome: Is there a difference? Nat. Clin. Pract. Nephrol. 2007;3:637. https://doi.org/10.1038/ncpneph0673.

[125] Seo Y, Yates B, Dizona P, Laframboise L, Norman J. Predictors of cognitive/affective and somatic depression in heart failure patients. Clin Nurs Res. 2014;23:259-80. https://doi.org/10.1177/1054773812473476.

[126] Shankar A, Klein R, Klein BE. The association among smoking, heavy drinking, and chronic kidney disease. Am J Epidemiol. 2006;164(3):26371. https://doi.org/10.1093/aje/kwj173.

[127] Shankar A, McMunn A, Banks J, Steptoe A. Loneliness, social isolation, and behavioral and biological health indicators in older adults. Health Psychol. 2011 Jul;30(4):377-85. https://doi.org/10.1037/a0022826.

[128] Shiovitz-Ezra S, Litwin H. Social network type and health-related behaviors: Evidence from an American national survey. Soc Sci Med. 2012; 75(5): 901-904. https://doi.org/10.1016/j.socscimed.2012.04.031.

[129] Smith KJ, Gavey S, RIddell NE, Kontari P, Victor C. The association between loneliness, social isolation and inflammation: A systematic review and meta-analysis. Neurosci Biobehav Rev. 2020 May;112:519-541. https://doi.org/10.1016/j.neubiorev.2020.02.002.

[130] Sorace, P, LaFontaine T, Thomas T R. Know the Risks: Lifestyle Management of Dyslipidemia. ACSM's Health \& Fitness Journal: July-August 2006 - Volume 10 - Issue 4 - p 18-25. https://doi.org/10.1249/00135124-200607000-00007.

[131] Srivastava A., Kaze A.D., McMullan C.J., Isakova T., Waikar S.S. Uric acid and the risks of kidney failure and death in individuals with CKD. Am. J. Kidney Dis. 2017;71:362-370. https://doi.org/10.1053/j.ajkd.2017.08.017.

[132] Steptoe A. and Kivimaki M. Stress and cardiovascular disease: an update on current knowledge. Annu Rev Public Health 34: 337-354, 2013. https://doi.org/10.1146/annurev-publhealth-031912-114452.

[133] Steptoe A, Owen N, Kunz-Ebrecht SR, Brydon L. Loneliness and neuroendocrine, cardiovascular, and inflammatory stress responses in middleaged men and women. Psychoneuroendocrinology. 2004 Jun;29(5):593-611. https://doi.org/10.1016/S0306-4530(03)00086-6.

[134] Stickley A, Koyanagi A, Koposov R, Blatny M, Hrdlicka M, Schwab-Stone M, et al. Loneliness and its association with psychological and somatic health problems among Czech, Russian and U.S. adolescents. BMC Psychiatry. 2016;16:128 https://doi.org/10.1186/s12888-016-0829-2.

[135] Tharrey M, Mariotti F, Mashchak A, et al. Patterns of plant and animal protein intake are strongly associated with cardiovascular mortality: the Adventist Health Study-2 cohort. Int J Epidemiol. 2018;47:1603-12. https://doi.org/10.1093/ije/dyy030.

[136] Theeke LA, Goins RT, Moore J, Campbell H. Loneliness, depression, social support, and quality of life in older chronically ill Appalachians. Journal of Psychology. 2012;146(1-2):155-171. https://doi.org/10.1080/00223980.2011.609571.

[137] Theeke L, Horstman P, Mallow J, et al. Quality of life and loneliness in stroke survivors living in Appalachia. J Neurosci Nurs. 2014;46(6):E3E15. https://doi.org/10.1097/JNN.0000000000000097.

[138] Theeke LA, Mallow JA, Moore J, McBurney A, Rellick S, VanGilder R. Effectiveness of LISTEN on loneliness, neuroimmunological stress response, psychosocial functioning, quality of life, and physical health measures of chronic illness. Int J Nurs Sci. 2016 Sep;3(3):242-251. https://doi.org/10.1016/j.ijnss.2016.08.004

[139] Tilvis RS, Laitala V, Routasalo PE, Pitkala KH. Suffering from loneliness indicates significant mortality risk of older people. J Aging Res. 2011;2011:534781. https://doi.org/10.4061/2011/534781.

[140] Valtorta NK, Kanaan M, Gilbody S, et al. Loneliness and social isolation as risk factors for coronary heart disease and stroke: systematic review and meta-analysis of longitudinal observational studies. Heart 2016;102:1009-16. https://doi.org/10.1136/heartjnl-2015-308790.

[141] Valtorta NK, Kanaan M, Gilbody S, Hanratty B. Loneliness, social isolation and risk of cardiovascular disease in the English Longitudinal Study of Ageing. Eur J Prev Cardiol. 2018;25(13):1387-1396. https://doi.org/10.1177/2047487318792696.

[142] Vargas J, Junco M, Gomez C, Lajud N. Early Life Stress Increases Metabolic Risk, HPA Axis Reactivity, and Depressive-Like Behavior When Combined with Postweaning Social Isolation in Rats. PLoS One. 2016;11(9):e0162665. Published 2016 Sep 9. https://doi.org/10.1371/journal.pone.0162665.

[143] Victor CD, Scambler SJ, Bowling A, Bondt J. The prevalence of and risk factors for loneliness in later life: A survey of older people in Great Britain. Ageing \& Society. 2005;25:357-375. https://doi.org/10.1017/S0144686X04003332.

[144] Walker E, Ploubidis G, Fancourt D. Social engagement and loneliness are differentially associated with neuro-immune markers in older age: Time-varying associations from the English Longitudinal Study of Ageing. Brain Behav Immun. 2019;82:224-229. https://doi.org/10.1016/j.bbi.2019.08.189.

[145] Wang YQ, Li R, Zhang MQ, Zhang Z, Qu WM, Huang ZL. The Neurobiological Mechanisms and Treatments of REM Sleep Disturbances in Depression. Curr Neuropharmacol. 2015;13(4):543-553. https://doi.org/10.2174/1570159X13666150310002540.

[146] Welsh JA, Sharma A, Cunningham SA, Vos MB. Consumption of added sugars and indicators of cardiovascular disease risk among US adolescents. Circulation. 2011;123(3):249-257. https://doi.org/10.1161/CIRCULATIONAHA.110.972166.

[147] Whisman MA. Loneliness and the metabolic syndrome in a population-based sample of middle-aged and older adults. Health Psychol. 2010 Sep;29(5):550-4. https://doi.org/10.1037/a0020760.

[148] WHO.int available at https://www.who.int/cardiovascular_diseases/about_cvd/en/ - accessed October 29, 2020

[149] Wilson RS, Krueger KR, Arnold SE, Schneider JA, Kelly JF, Bennett DA. Loneliness and risk of Alzheimer disease. Archives of General Psychiatry. 2007;64:234-240. https://doi.org/10.1001/archpsyc.64.2.234. 
[150] Xia N, Li H. Loneliness, Social Isolation, and Cardiovascular Health. Antioxid Redox Signal. 2018;28(9):837-851. https://doi.org/10.1089/ars.2017.7312.

[151] Ziggi Ivan Santini, Katherine Leigh Fiori, et al. Social relationships, loneliness, and mental health among older men and women in Ireland: A prospective community-based study.Journal of Affective Disorders. Volume 204, 2016, Pages 59-69. https://doi.org/10.1016/j.jad.2016.06.032.

[152] Zilioli S, Slatcher RB, Chi P, Li X, Zhao J, Zhao G. The impact of daily and trait loneliness on diurnal cortisol and sleep among children affected by parental HIV/AIDS. Psychoneuroendocrinology. 2017;75:64-71. https://doi.org/10.1016/j.psyneuen.2016.10.012. 